
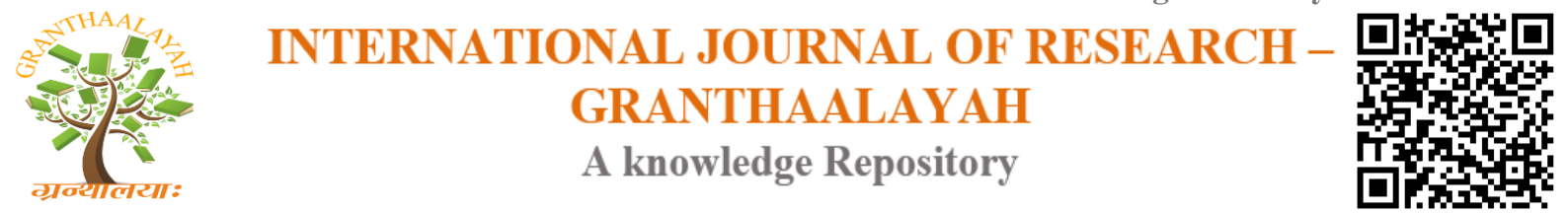

Science

\title{
ASSESSMENT OF IRON STATUS AMONG SUDANESE MENOPAUSAL WOMEN
}

\author{
Siham Khalifa Abd Allah ${ }^{* 1}$, Mohamed Abedelrahman Syid ${ }^{2}$, Areeg Alsail Mohmmed ${ }^{3}$, \\ Raian Bakhet Yassein ${ }^{4}$, Nosiba Abdelmajid Alballah ${ }^{5}$, Nada Omer Alseedig ${ }^{6}$ \\ ${ }^{* 1}$ Hematology Department, Faculty of Medical Laboratory Sciences, Shendi University, \\ SUDAN \\ ${ }^{2}$ Hematology Department, Faculty of Medical Laboratory Sciences, Shendi University, Lecturer, \\ SUDAN \\ 3, 4, 5, 6 Hematology Department, Faculty of Medical Laboratory Sciences, Shendi University, \\ SUDAN
}

\begin{abstract}
Menopause is very important turning phase in the life of a female and is associated with hormonal changes. These hormones affect the overall personality however menopause is also associated with varied menopausal symptoms. Menopause women are a high risk group for iron level disturbance in your bodies.

This was descriptive cross-sectional study aimed to determine the serum iron level in menopause women. Following informed consent, fifty subjects in menopause period, and sex matched fifty healthy premenopausal subjects as controls were enrolled. Serum iron was measured using spectrophotometer.

Mean of serum iron level was significantly lower among menopause women when compared with the premenopausal women (control) (P.value 0.04). There was significant changing in serum iron level according to age duration (P.value 0.000).

We observed changes in iron level between menopausal women when compared with premenopausal women, this study confirm iron deficiency among menopause women. Also observed that the level of serum iron decreased in certain age just after beginning menopause then increased in certain age and return also to decrease with increased of age.
\end{abstract}

Keywords:

Premenopause, Menopause, Serum Iron, Sudan.

Cite This Article: Siham Khalifa Abd Allah, Mohamed Abedelrahman Syid, Areeg Alsail Mohmmed, Raian Bakhet Yassein, Nosiba Abdelmajid Alballah, and Nada Omer Alseedig, "ASSESSMENT OF IRON STATUS AMONG SUDANESE MENOPAUSAL WOMEN" International Journal of Research - Granthaalayah, Vol. 4, No. 2 (2016): 107-110. 


\section{INTRODUCTION}

Menstruation is a unique physiological phenomenon in young women, characterized by the periodic high levels of estrogen and the shedding of the endometrium. Because of this monthly blood loss, iron deficiency is prevalent in premenopausal women ${ }^{(1)}$.

Menopause is a natural aging process during which a women passes from the reproductive to the non-reproductive years. despite this natural process, many women still experience menopausal symptoms such as vasomotor episodes or 'hot flashes' urinary incontinence, vaginal change, breast change, thinning of the skin, bone loss, as well as path physiologic conditions such as bone mineral density and drying of skin ${ }^{(2)}$.

Menopause refers to the permanent cessation of menstruation due to loss of ovarian follicular activity. It results in a decrease in estrogen secretion that is responsible for most of the features seen in menopausal women ${ }^{(3)}$.

Iron is essential for oxygen transport, electron transfer reactions, gene regulation, and regulation of cell growth and differentiation. Excessive iron, however, can damage tissues by catalyzing the conversion of hydrogen peroxide to free radical ions that attack cellular membranes, proteins, and DNA ${ }^{(4-7)}$. Although healthy levels of iron in human body have not yet been established, it is conceivable that iron imbalance (deficiency or overload) could cause adverse health effects, for example it has been postulated that iron deficiency in young women plays a role in a high breast cancer recurrence in young patients, and increased iron contributes to a high breast cancer incidence in postmenopausal women ${ }^{(10)}$. Whereas estrogen decreases because of the cessation of ovarian functions, iron increases as a result of decreasing menstrual periods ${ }^{(11-12)}$.

\section{MATERIALS AND METHODS}

This was a cross-sectional descriptive study for data collected from woman in Shendi locality, river Nile state, northern Sudan. Study was carried out on one hundred women, fifty of them with aged 46 years and more were menopausal (women were defined as menopausal if they had no menses for $\geq 12$ months), while fifty women, aged 20-35 years were premenopausal and served as control (We excluded women who were using estrogen or progestin therapy at the premenopausal or menopausal). Menopausal women included in the study group were amenorrhoeic due to a natural cause without a hysterectomy or other procedure that would have stopped their menses. The investigation was performed on venous blood sample drawn into plain tubes then centrifuge at $20^{\circ} \mathrm{C}, 1500 \mathrm{~g}$ for 10 minutes to collect serum sample, then estimated the iron spectrophotometrically due to color that performed by this method in which transferrin bound ferric iron in the sample are release by guanidinium and reduced to ferrous by mean of hydroxylamine, ferrous iron react with ferrozine forming a coloured complex. The study was undertaken after obtaining consent from the participants. Data was analyzed by using SPSS-20 (statistical packaged for social science) computer program. 


\section{RESULTS AND DISCUSSION}

Table 1: Show the mean of serum iron among menopause and premenopause women

\begin{tabular}{|l||l|l|}
\hline State & Mean $\boldsymbol{\mu g} / \mathbf{d l}$ & P.value \\
\hline \hline Menopause & $59.1 \mu \mathrm{g} / \mathrm{dl}$ & \multirow{2}{*}{0.04} \\
\hline Premenopause & $61.4 \mu \mathrm{g} / \mathrm{dl}$ & \\
\hline
\end{tabular}

Table 2: Show the change of the mean of serum iron according to age group

\begin{tabular}{|l|l|l|}
\hline age group & Mean $\mu \mathrm{g} / \mathrm{dl}$ & P.value \\
\hline 46-51 years & $53.9 \mu \mathrm{g} / \mathrm{dl}$ & \multirow{2}{*}{0.000} \\
\hline $52-57$ years & $69.8 \mu \mathrm{g} / \mathrm{dl}$ & \\
\hline $\begin{array}{l}\text { More than } 57 \\
\text { years }\end{array}$ & $55.7 \mu \mathrm{g} / \mathrm{dl}$ & \\
\hline
\end{tabular}

In this study there was a decreased in mean of the serum iron $(59.1 \mu \mathrm{g} / \mathrm{dl})$ in menopausal women when compared with premenopausal women $(61.4 \mu \mathrm{g} / \mathrm{dl}$ ) (P.value 0.04). This result disagreement with previous studies (5-6).

There was significant changing in serum iron level according to age duration in which its decreased in the period just after menopause beginning ( $46-51$ years), mean serum iron was $(53.9 \mu \mathrm{g} / \mathrm{dl})$, then increased to reach $(69.8 \mu \mathrm{g} / \mathrm{dl})$ in the period $(52-57$ years $)$ and finally decreased to $(55.7 \mu \mathrm{g} / \mathrm{dl})$ in the period more than 57 years old with (P.value 0.000). In my opinion the increased in the period after menopause beginning was due to stop of menstrual time in which the iron loss during menstrual cycle, then decreased in iron level due to aging process. Menstruation is a unique physiological phenomenon in young women, characterized by the periodic high levels of estrogen and the shedding of the endometrium. Because of this monthly blood loss, iron deficiency is prevalent in premenopausal women. During perimenopause, fewer eggs exist for the ovaries to stimulate, and menstrual periods become irregular. This period of fluctuation can last up to 10 years. Cessation of menstruation marks the later stage of perimenopause. Because iron is no longer lost through menstruation, it accumulates in the body (1), also another previous study showed increased serum ferritin from $4.8 \mathrm{mg} / \mathrm{kg}$ bodyweight at the beginning of perimenopause at age 45 years to $12 \mathrm{mg} / \mathrm{kg}$ body weight after menopause at age 60 years, which lead to increase serum iron in menopause women (9), which insure that increasing of iron level after beginning menopausal period, but this increased will stop due to aging process. Also in the present study decreased in iron level in menopausal women with age more than 57 years old agreement with fact that explain by previous study in which there was little direct evidence of a high prevalence of iron deficiency in the elderly (8). 


\section{CONCLUSION}

We observed changes in iron level between menopausal women when compared with premenopausal women, this study confirm iron deficiency among menopause women. Also observed that the level of serum iron decreased in certain age just after beginning menopause then increased in certain age and return also to decrease with increased of age.

\section{REFERENCES}

[1] Zimmermann MB and Hurrell RF. Nutritional iron deficiency. Lancet 370: 511-520, 2007.

[2] Nelson HD. Menopause. Lancet 371: 760-770, 2008.

[3] Thirup, P., 2003. Haematocrit: Within subject and seasonal variation. Sports Med., 33(3): $231-243$.

[4] Andrews NC. Disorders of iron metabolism. N Engl J Med 1999;341:1986-95.

[5] Betsy L. Crist, M, D. Lee Alekel, Laura M. Ritland, Laura N. Hanson, Ulrike Genschel and Manju B. Reddy. Association of Oxidative Stress, Iron, and Centralized Fat Mass in Healthy Postmenopausal Women. J Womens Health (Larchmt). 2009 Jun; 18(6): 795-801.

[6] Khansa Qamar, Muhammad Saboor, Fatima Qudsia, Shafi Muhammad Khosa, Moinuddin and Muhammad Usman. Malabsorption of iron as a cause of iron deficiency anemia in postmenopausal women. Pak J Med Sci. 2015 Mar-Apr; 31(2): 304308.

[7] Beard JL. Iron biology in immune function, muscle metabolism and neuronal functioning. J Nutr 2001;131:568S-80S

[8] Lynch SR, Finch CA, Monsen ER, Cook JD. Iron status of elderly Americans. Am J Clin Nutr. 1982 Nov;36(5 Suppl):1032-45.

[9] Jinlong Jian, Edward Pelle and Xi Huang. Iron and Menopause: Does Increased Iron Affect the Health of Postmenopausal Women?. Antioxid Redox Signal. 2009 Dec; 11(12): 2939-2943.doi: 10.1089/ars.2009.2576

[10] Huang X. Does iron have a role in breast cancer? Lancet Oncol. 2008;9:803-807. [PMC free article][PubMed].

[11] Milman N. Kirchhoff M. Iron stores in 1359, 30- to 60-year-old Danish women: evaluation by serum ferritin and hemoglobin. Ann Hematol. 1992;64:22-27. [PubMed].

[12] Zacharski LR. Ornstein DL. Woloshin S. Schwartz LM. Association of age, sex, and race with body iron stores in adults: analysis of NHANES III data. Am Heart J. 2000;140:98104. [PubMed]. 